УДК 655.531

\title{
ДОСЛІДЖЕННЯ КОЛЬОРОВІДТВОРЕННЯ НА ОДНО- ТА ДВОШАРОВОМУ ПАПЕРІ СПЕЦІАЛЬНОГО ПРИЗНАЧЕННЯ
}

( Т. Ю. Киричок, к.т.н., доцент, НТУУ «КПІ», В. М. Нестеренко, інженер, НБУ, Н. Л. Талімонова, аспірантка, НТУУ «КПІ», Київ, Україна

Определены и сопоставлены физико-технологические параметры исследуемых образцов бумаги и краски. Исследованы цветовые характеристики оттисков, построены графики зависимости цветовых различий от толщины красочного слоя. Определена зависимость оптической плотности оттисков от толщины красочного слоя.

The physical and technological parameters of paper and ink test specimens were defined and compared. The researches of color characteristics of the prints, plotted as a function of color shift on the thickness of the ink layer. The dependences of the prints optical density from ink layer thickness are determined.

\section{Постановка проблеми}

Для підвищення захисних та міцнісних властивостей банкнот та інших цінних паперів та документів суворого обліку (ЦПДСО) у світі розробляються та досліджуються нові види паперу. Зокрема, це - захищений двошаровий папір, виготовлений за безформальдегідною технологією.

При використанні двошарового паперу можлива дещо інша його поведінка в процесі друку порівняно з одношаровим папером; може відрізнятись показник фарбосприйняття, інші фізичні та оптичні показники паперу i, як результат, - колірність, насиченість та час висихання фарбових відбитків. Тому, застосування нових матеріалів вимагає дослідження впливу параметрів цих матеріалів на друкарсько-технічні властивості та на якість поліграфічної продукції [1].

\section{Аналіз попередніх} досліджень

Дослідження тенденцій розвитку методів захисту ЦПДСО на основі вивчення результатів патентного пошуку [2] дає підстави стверджувати, що захист паперового полотна $є$ пріоритетним напрямом розробок у сфері виготовлення ЦПДСО, оскільки цьому напряму захисту присвячено понад 15 \% патентів 2000-2009 років. Така тенденція підтверджена й в роботі [3], де показано, що захисту паперу присвячено понад 11\% патентів за 2005-2008 роки зі стійкою тенденцією до зростання (12 \% щорічно). Найбільша кількість розробок стосується створення захищеного паперу, яке пропонується у декількох напрямках: розробка нових видів водяних знаків, використання багатошарових структур, включення захисних стрічок. Така стійка тенденція збільшення уваги до за- 
хисту паперового полотна зберігається протягом тривалого часу [4].

Окрім власне питань захисту паперу, увага розробників захищеного паперу спрямована на створення паперу з підвищеною стійкістю до забруднення та механічних пошкоджень [5]. Зокрема, це розробки двошарового банкнотного паперу $[6,7]$.

\section{Мета роботи}

Метою даної роботи є дослідження впливу структури, фізико-механічних і колірних характеристик двошарового паперу спеціального призначення, виготовленого за безформальдегідною технологією на друкарськотехнічні властивості та якість поліграфічної продукції спеціального призначення.

Таблиця 1

Характеристики паперу

\begin{tabular}{|c|c|c|c|c|}
\hline \multirow[b]{2}{*}{ № } & \multirow[b]{2}{*}{ Параметри паперу } & \multirow[b]{2}{*}{ Одиниці } & \multicolumn{2}{|c|}{ Папір } \\
\hline & & & $\begin{array}{c}\text { Одноша- } \\
\text { ровий }\end{array}$ & $\begin{array}{c}\text { Двошаро } \\
\text { вий }\end{array}$ \\
\hline 1 & Товщина & MKM & $109 \pm 3,0$ & $107 \pm 2,5$ \\
\hline 2 & Maca $1 \mathrm{~m}^{2}$ & $\Gamma / \mathrm{M}^{2}$ & 87,0 & 86,5 \\
\hline 3 & Вологість & $\%$ & 6,8 & 6,9 \\
\hline 4 & Лінійна деформація при зволоженні & $\%$ & 2,0 & 2,1 \\
\hline 5 & $\begin{array}{l}\text { Поверхнева вбирність: } \\
\text { сіточна сторона } \\
\text { верхня сторона }\end{array}$ & $\Gamma / M^{2}$ & $\begin{array}{l}30,5 \pm 3,0 \\
31,5 \pm 2,0\end{array}$ & $\begin{array}{l}28,0 \pm 5,0 \\
28,5 \pm 1,5\end{array}$ \\
\hline 6 & Ph водної витяжки & & 6,6 & 6,6 \\
\hline 7 & $\begin{array}{l}\text { Шорсткість: } \\
\text { сіточна сторона } \\
\text { верхня сторона }\end{array}$ & мл/хв. & $\begin{array}{l}377 \\
384\end{array}$ & $\begin{array}{l}340 \\
350\end{array}$ \\
\hline 8 & Непрозорість & $\%$ & 90,0 & 88,8 \\
\hline 9 & Абсолютний опір роздиранню & $\mathrm{MH}$ & 870 & 840 \\
\hline 10 & $\begin{array}{l}\text { Подвійні згини: } \\
\text { машинний напрямок } \\
\text { поперечний напрямок }\end{array}$ & & $\begin{array}{l}5422 \\
3421\end{array}$ & $\begin{array}{l}5499 \\
3561\end{array}$ \\
\hline 11 & $\begin{array}{l}\text { Руйнівне зусилля: } \\
\text { машинний напрямок } \\
\text { поперечний напрямок }\end{array}$ & $\mathrm{H}$ & $\begin{array}{c}113 \\
61\end{array}$ & $\begin{array}{c}127 \\
58\end{array}$ \\
\hline 12 & $\begin{array}{l}\text { Відносне подовження: } \\
\text { машинний напрямок } \\
\text { поперечний напрямок }\end{array}$ & $\%$ & $\begin{array}{c}5,0 \\
10,0\end{array}$ & $\begin{array}{l}4,7 \\
9,1\end{array}$ \\
\hline 13 & Зольність & $\%$ & 2,4 & 2,3 \\
\hline 14 & $\begin{array}{l}\text { Повітропроникність: } \\
\text { сіточна сторона } \\
\text { верхня сторона }\end{array}$ & мл/Хв. & $\begin{array}{l}25,8 \\
26,2\end{array}$ & $\begin{array}{l}24,8 \\
25,2\end{array}$ \\
\hline
\end{tabular}


Таблиця 2

Реологічні та колірні характеристики друкарських фарб

\begin{tabular}{|c|c|c|c|c|c|}
\hline \multirow{2}{*}{ Фарба } & \multirow{2}{*}{$\begin{array}{c}\text { Липкість, } \\
\text { кДж }\end{array}$} & \multirow{2}{*}{$\begin{array}{c}\text { Вязкість, } \eta, \\
\text { Па.с }\end{array}$} & \multicolumn{3}{|c|}{ Колірні характеристики } \\
\hline & & & $L^{*}$ & $a^{*}$ & $b^{*}$ \\
\hline Червона & 226,0 & 6,134 & 39,33 & 44,3 & 20,13 \\
\hline Жовта & 206,0 & 6,848 & 74,25 & 11,12 & 71,56 \\
\hline Синя & 224,0 & 7,290 & 27,02 & 6,16 & $-14,09$ \\
\hline
\end{tabular}

\section{Результати проведених} досліджень

Для проведення експериментальних досліджень було використано два види паперу спеціального призначення - одно- та двошаровий. В табл. 1 наведено їх фізико-технічні характеристики, які було визначено експериментально [8-12]. Відбитки були виготовлені на цих паперах спеціальною напівпрозорою фарбою, реологічні та колірні характеристики якої наведено в табл. 2. Рецептура фарби була розроблена і виготовлена за допомогою програми Data Color [13]. Тестові відбитки були отримані в лабораторних умовах на прободрукарському приладі IGT Reprotest B. V.

Встановлено, що фізико-технологічні характеристики однота двошарового паперу дещо відрізняються. Двошаровий папір має кращі структурно-механічні властивості (менше відносне подовження, більше руйнівне зусилля та стійкість до згинів). Крім того, двошаровий папір є більш гладким (має меншу шорсткість) та менш пористим (має меншу повітропроникність з обох сторін). Останне може бути причиною меншої поверхневої вбирності двошарового паперу. Загалом, відмінності всіх

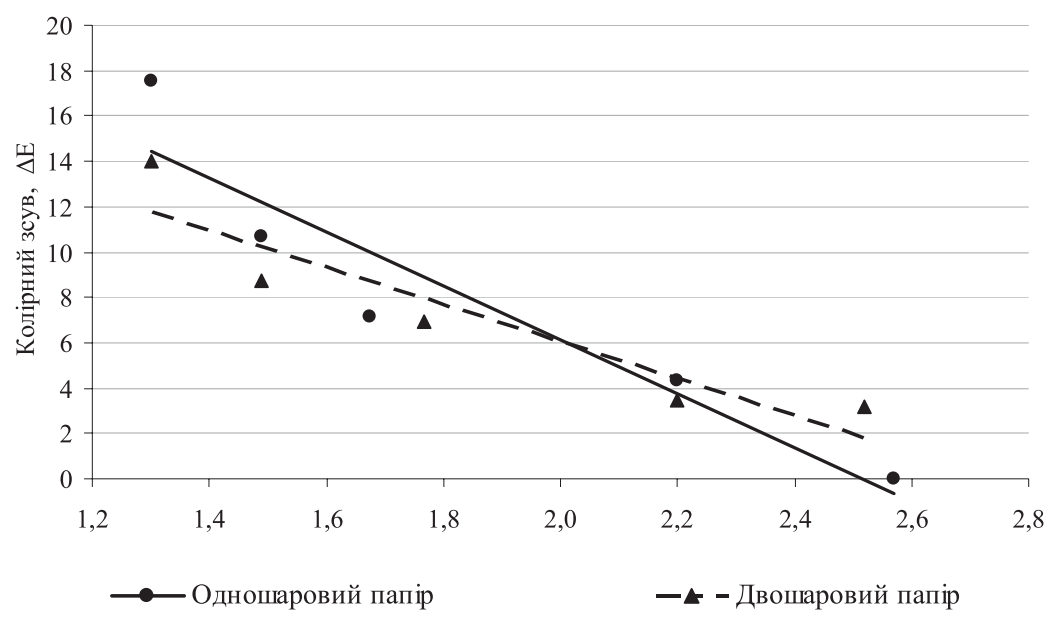

Рис. 1. Залежність колірного зсуву відносно відбитка з найбільшою товщиною фарбового шару $\left(\Delta \mathrm{E}_{1}\right)$ від товщини фарбового шару (червона фарба) 
параметрів одно- та двошарового паперу не перевищують $12 \%$.

Для дослідження ідентичності кольоровідтворення на різних видах паперу, було визначено колірний зсув відбитків, отриманих на верхній стороні однота двошарового паперу. Колірні характеристики відбитків для кожної фарби порівнювались із ко- лірними характеристиками задрукованої найбільшою кількістю відповідної фарби верхньої сторони одношарового паперу $\left(\Delta \mathrm{E}_{1}\right)$ та з колірними характеристиками самих друкарських фарб $\left(\Delta \mathrm{E}_{2}\right)$. Графіки залежності $\Delta \mathrm{E}_{1}$ та $\Delta \mathrm{E}_{2}$ від товщини фарбового шару на від-битку представлені на рисунках 1-6.

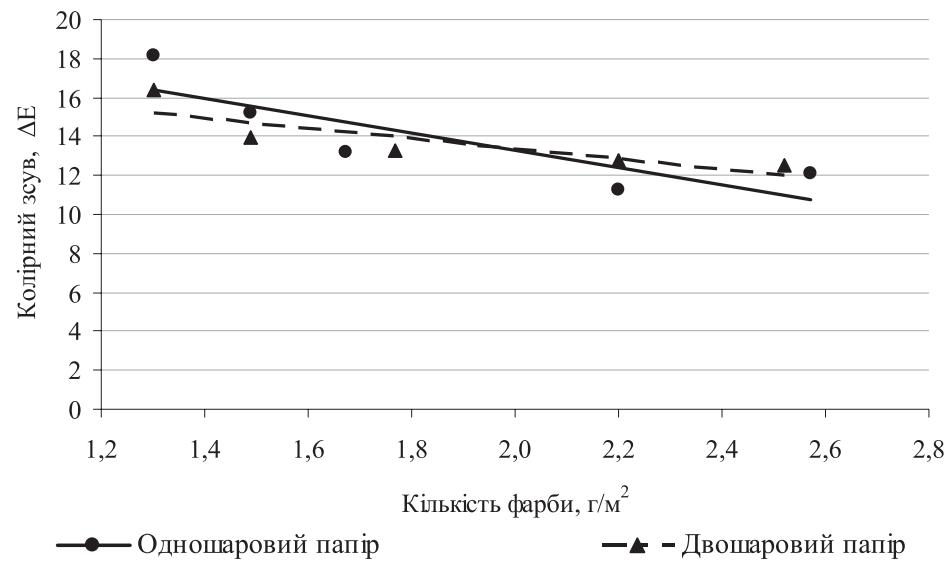

Рис. 2. Залежність колірного зсуву відбитка відносно кольору фарби ( $\left.\Delta \mathrm{E}_{2}\right)$ від товщини фарбового шару (червона фарба)

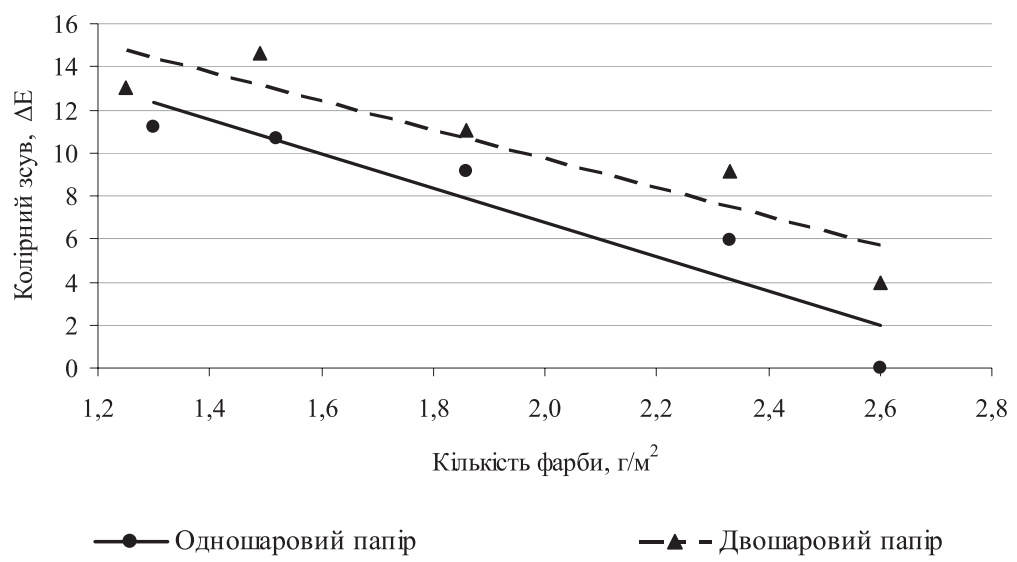

Рис. 3. Залежність колірного зсуву відносно відбитка з найбільшою товщиною фарбового шару $\left(\Delta \mathrm{E}_{1}\right)$ від товщини фарбового шару (жовта фарба) 


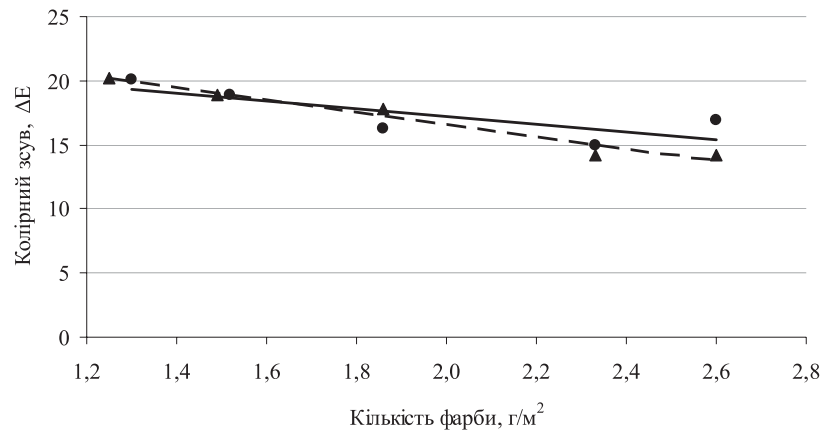

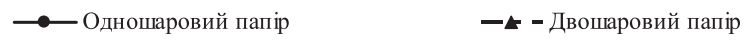

Рис. 4. Залежність колірного зсуву відбитка відносно кольору фарби $\left(\Delta \mathrm{E}_{2}\right)$ від товщини фарбового шару (жовта фарба)

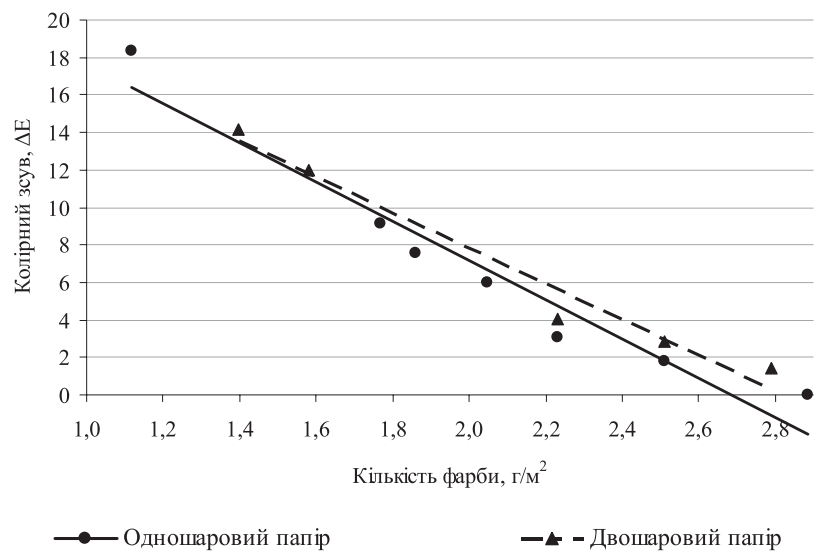

Рис. 5. Залежність колірного зсуву відносно відбитка з найбільшою товщиною фарбового шару $\left(\Delta \mathrm{E}_{1}\right)$ від товщини фарбового шару (синя фарба)

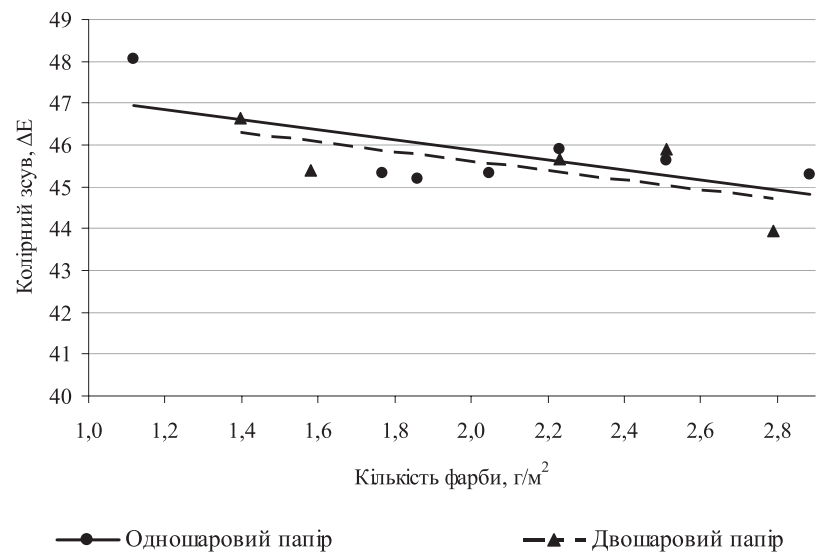

Рис. 6. Залежність колірного зсуву відбитка відносно кольору фарби ( $\left.\Delta \mathrm{E}_{2}\right)$ від товщини фарбового шару (синя фарба) 
Визначення оптичної густини проводилося за допомогою денситометра GretagMacbeth D19C. На основі отриманих даних були побудовані графіки залежності оптичної густини від товщини фарбового шару на відбитках, отриманих на двох видах паперу трьома фарбами (рис. 7-18).

В результаті аналізу отриманих значень встановлено залежність оптичної густини фарбових відбитків від товщини фарбового шару для фарб трьох різних кольо- рів (червоної, жовтої, синьої) для одно- та двошарового паперу спеціального призначення. Виявлено, що рівень оптичної густини $\mathrm{D}=0,8$ досягається при товщині фарбового шару 1,2 г/м² для синьої фарби, 1,3 г/м² для жовтої фарби, 1,6 г/м² для червоної фарби для обох видів паперу (однота двошарового). Встановлено, що з точки зору оптичної густини відбитків зразки, віддруковані на одно- та двошаровому папері, не мають суттєвих відмінностей.

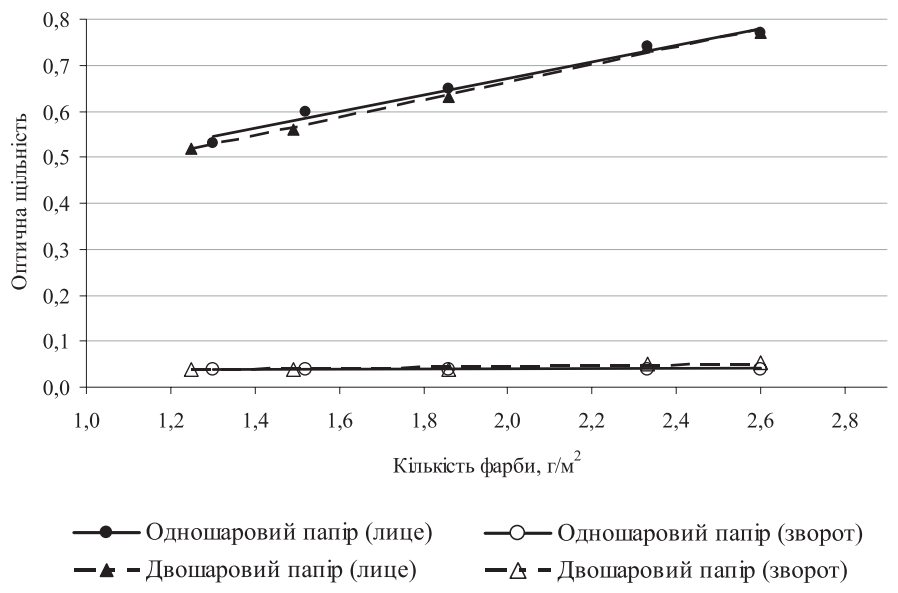

Рис. 7. Залежність оптичної щільності зразків, віддрукованих червоною фарбою за складовою Black

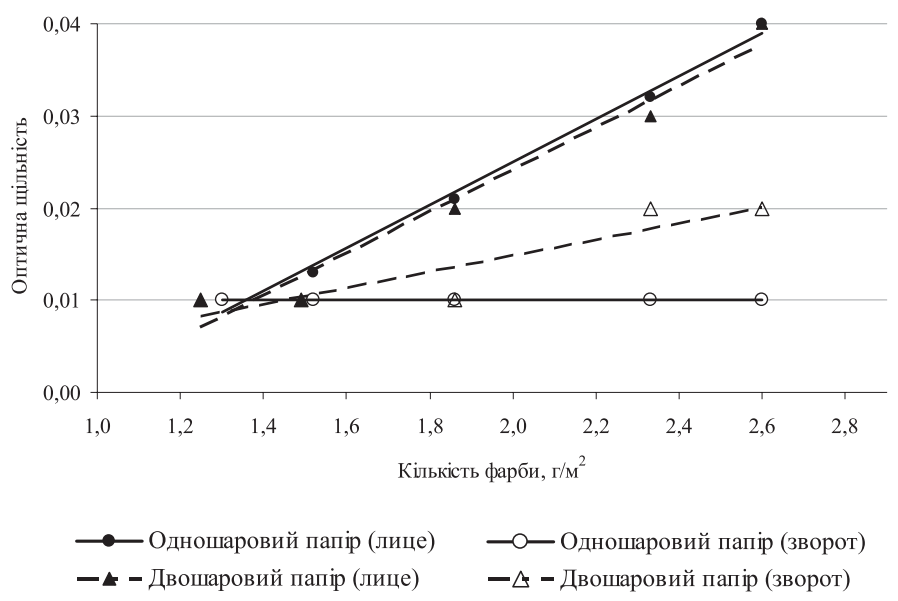

Рис. 8. Залежність оптичної щільності зразків, віддрукованих червоною фарбою за складовою Cyan 


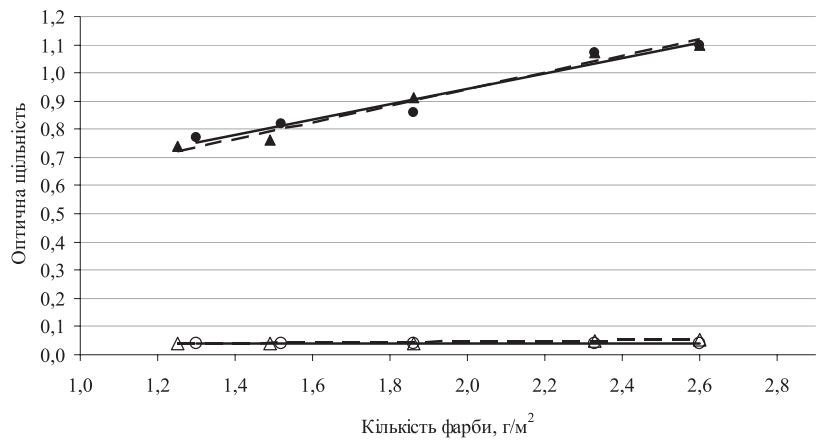

$$
\begin{array}{ll}
\longrightarrow \text { — Одношаровий папір (лице) } & -0 \text { Одношаровий папір (зворот) } \\
\mathbf{- \star}-\text { - Двошаровий папір (лице) } & -\Delta-\text { Двошаровий папір (зворот) }
\end{array}
$$

Рис. 9. Залежність оптичної щільності зразків, віддрукованих червоною фарбою за складовою Magenta

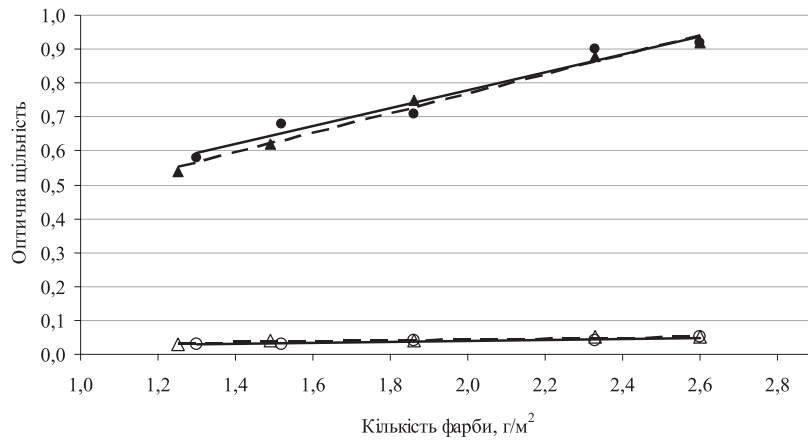

$$
\begin{array}{ll}
\longrightarrow \text { - Одношаровий папір (лице) } & \longrightarrow \text { - Одношаровий папір (зворот) } \\
-\star-\text { - Двошаровий папір (лице) } & -\Delta-\text { Двошаровий папір (зворот) }
\end{array}
$$

Рис. 10. Залежність оптичної щільності зразків, віддрукованих червоною фарбою за складовою Yellow

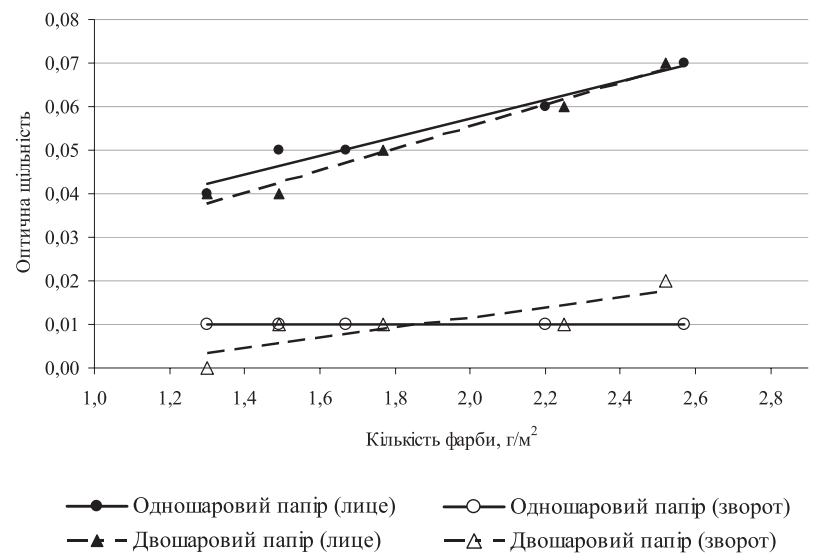

Рис. 11. Залежність оптичної щільності зразків, віддрукованих жовтою фарбою за складовою Black 


\section{ТЕХНОЛОГ І Ч Н І П РО ЦЕ С И}

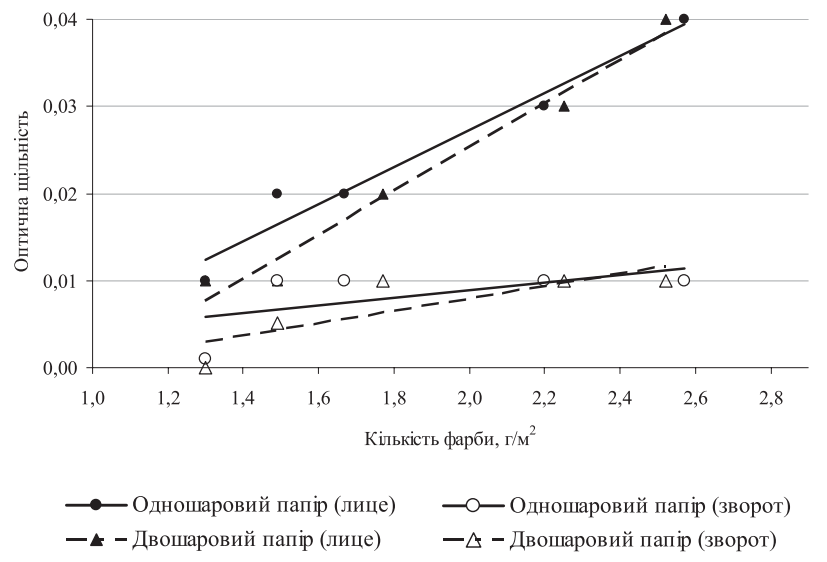

Рис. 12. Залежність оптичної щільності зразків, віддрукованих жовтою фарбою за складовою Cyan

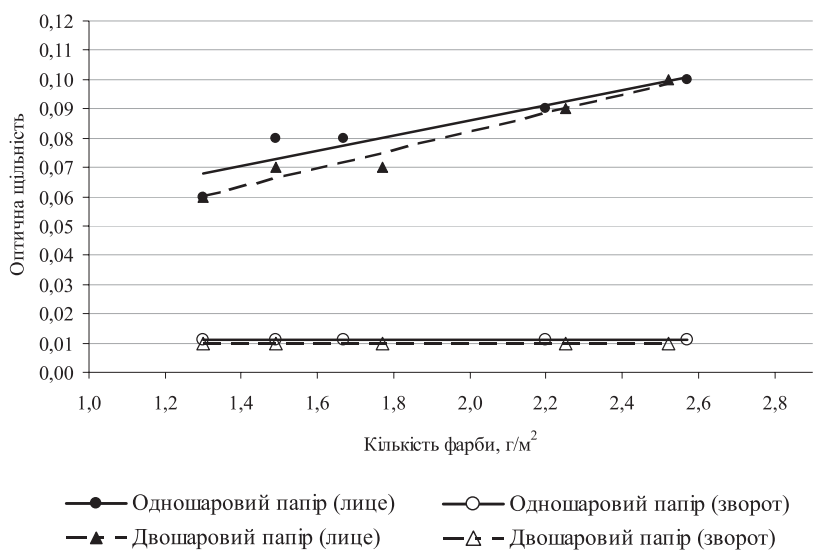

Рис. 13. Залежність оптичної щільності зразків, віддрукованих жовтою фарбою за складовою Magenta

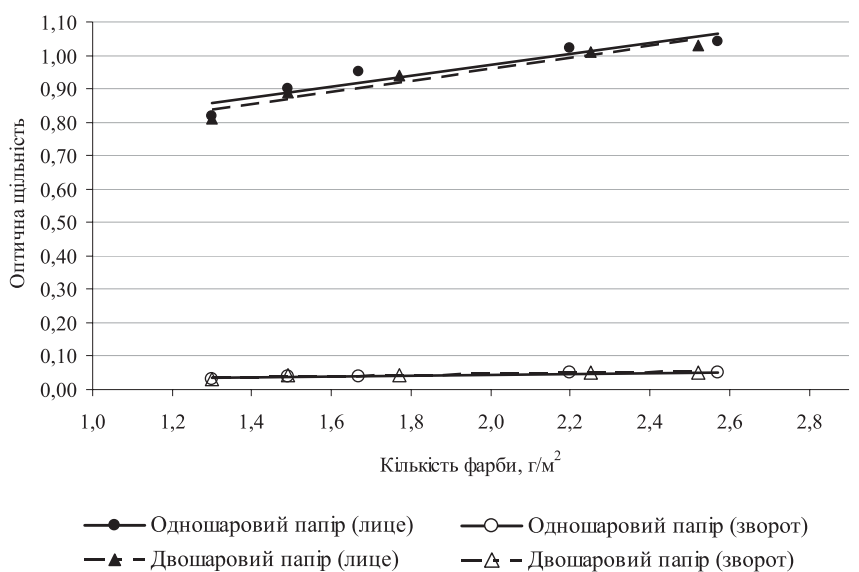

Рис. 14. Залежність оптичної щільності зразків, віддрукованих жовтою фарбою за складовою Yellow 


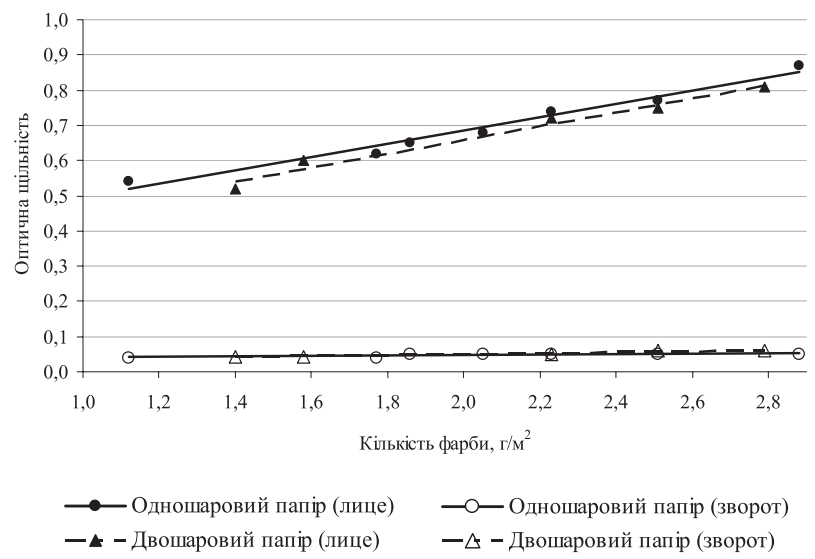

Рис. 15. Залежність оптичної щільності зразків, віддрукованих синьою фарбою за складовою Black

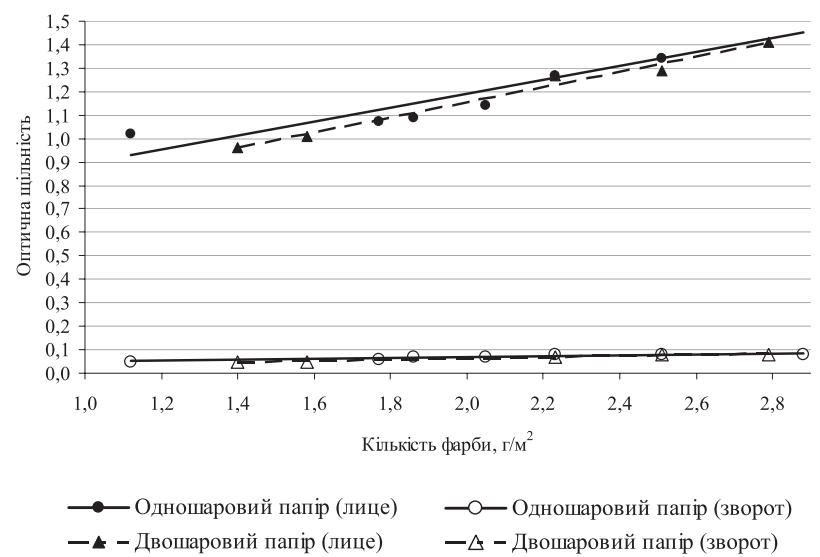

Рис. 16. Залежність оптичної щільності зразків, віддрукованих синьою фарбою за складовою Суan

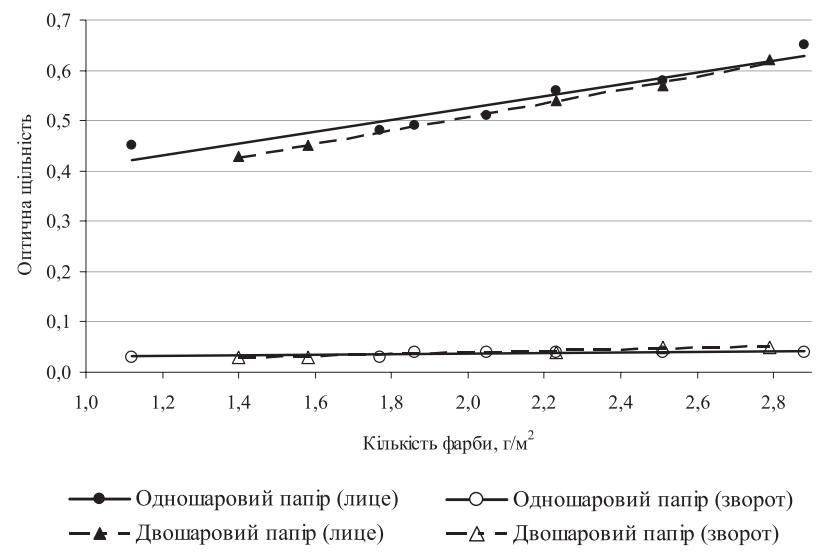

Рис. 17. Залежність оптичної щільності зразків, віддрукованих синьою фарбою за складовою Magenta 


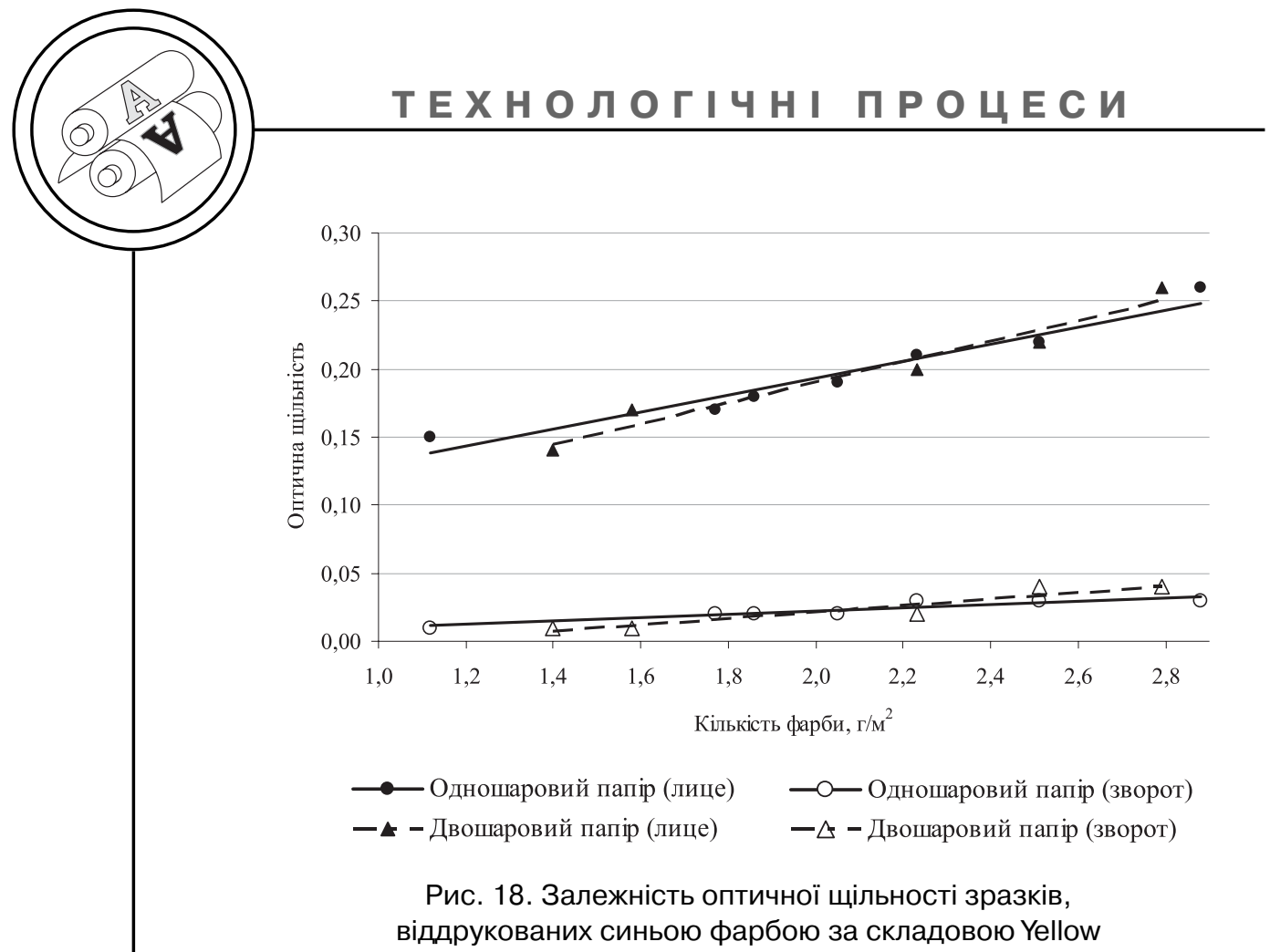

\section{Висновки}

Аналіз отриманих даних щодо колірного зсуву дає підстави стверджувати, що колірний зсув відбитків відносно колірних параметрів фарби зменшується практично лінійно для всіх досліджених фарб для обох видів паперу. При цьому абсолютні значення колірного зсуву як відносно відповідної фарби, так і відносно відбитка з найбільшою товщиною фарбового шару менші для двошарового паперу. Тому коректно зробити висновок про дотримання такого тренду для товщин фарбового шару, характерних для реальних умов офсетного друку (тобто

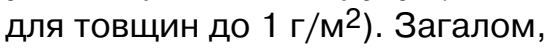
колірний зсув між одно- та двошаровим папером при однаковій товщині фарбового шару $€$ незначним $-\Delta \mathrm{E}$ не перевищуе трьох.
Складові $L^{*}, a^{*}, b^{*}$ колірної моделі CIELab відбитків на двошаровому папері $є$ більш наближеними до складових $L^{*}, a^{*}, b^{*}$ фарби.

Встановлено також, що з точки зору оптичної густини відбитків зразки, віддруковані на однота двошаровому папері, не мають суттєвих відмінностей.

Таким чином, двошаровий папір не тільки має кращі структурно-механічні властивості (менше відносне подовження, більше руйнівне зусилля та стійкість до згинів), є більш гладким (має меншу шорсткість) та менш пористим (має меншу повітропроникність з обох сторін), має меншу поверхневу вбирність, але й має кращі друкарсько-технічні властивості - дозволяе отримати відбитки з меншим колірним зсувом відносно фарби, тобто забезпечити краще кольоровідтворення. 
1. Козаровицький Л. А. Бумага и краска в процессе печатания / Л. А. Козаровицький. - М. : Книга, 1965. 2. Киричок Т. Ю.Тенденції досліджень та розробок у сфері захисту цінних паперів та документів суворого обліку / Т. Ю. Киричок, К. М. Беспала // Технологія і техніка друкарства. Зб. наук. праць. - К., 2010. - № 4(30). - C. 51-59. 3. Maurice Perron. Patenting of new banknote security features. - Billetaria. International Review on Cash Management. Issue 7, April 2010. - Р. 22-23. 4. Киричок П. О. Методи захисту цінних паперів та документів суворого обліку / П. О. Киричок, Ю. М. Коростіль, А. В. Шевчук. - К., 2008. 5. Ana Maria Gonsalez. Test on long-life paper / Ana Maria Gonsalez, Diego Schweckandt // Billetaria. International Review on Cash Management. - April 2011. - Issue 9. - P. 32. 6. Багатошаровий захищений папір [Текст] / Гизеке унд Дервиент ГМБХ. - Німеччина. 102005013474. - 23.03.2005. 7. Багатошаровий захисний матеріал та спосіб його виготовлення [Текст] / Кауттуа Пейпер Миллой, Альстром корпорейшн. - Фінляндія. - 20040806. - 11.06.2004. 8. Бумага. Методы определения прозрачности и непрозрачности: ГОСТ 8874-80. - ГОСТ 8874-80. [Чинний від 1981-01-01]. - (Міждержавний стандарт). 9. Папір та картон. Метод визначення повітропроникності (середній діапазон вимірювання). Метод Бендтсена: дСтУ ISO 5636-3:1984. - дСTУ ISO 5636-3:1984. [Чинний від 1993-07-01]. - К. : Держспоживстандарт України, 2006. - 181 с. - (Національні стандарти України). 10. Папір та картон. Метод визначення шорсткості (метод із застосуванням пропускання повітря). Метод Бендтсена: ДСТУ ISO 8791-2:1990. — ISO 8791-2:1990. - [Чинний від 199401-01]. - К. : Держспоживстандарт України, 2006. - 181 с. - (Національні стандарти України). 11. Бумага и картон. Метод определения поверхностной впитываемости воды при одностороннем смачивании (метод Кобба): ГОСТ 12605-97. - ГОСТ 12605-97. - [Чинний від 1997-11-21]. - (Міждержавний стандарт). 12. Бумага и картон. Метод определения поверхностной впитываемости капельным способом: ГОСТ 12603-67. - ГОСТ 12603-67. [Чинний від 1967-01-07]. - (Міждержавний стандарт). 13. Шевчук А. В. Захист друкованої продукції за допомогою змішування фарб / А. В. Шевчук, 3. Есенфельд // Друкарство. - 2000. - № 4(33). - С. 68-71. 